\title{
EKSISTENSI DAN KONTRIBUSI ULAMA PEREMPUAN DI KABUPATEN ACEH BARAT (SUATU ANALISIS PRAKTIK SOSIAL DARI BOURDIEU)
}

\author{
Irma Juraida \\ Jurusan Sosiologi \\ Falkultas Ilmu Sosial dan Politik \\ Universitas Teuku Umar \\ Irmajuraida2@gmail.com
}

\begin{abstract}
This study discusses about the existence and extent of the contribution of women religious leaders accepted in society in West Aceh district by using sociological analysis (social practice). This study was conducted in Aceh Barat district using a qualitative approach, notably through in-depth interview techniques by way of to-face and observation. According to the thinking of Bourdieu (1990), habitus and domains provide an easy way to see how the process of constructing of the realm of Islamic boarding school and the community and penginternalisasi habitus and religious values, socio-cultural and customs in society that formed the existence of women religious leaders in the community. . the results showed that the existence and contribution of women religious leaders in society, to understand the people of Aceh are still in the capacity of women. Women have not been possible to contribute to the public realm, just in taklim, special lectures for or fellow women and local preachers.
\end{abstract}

Keywords: Existence, contributions, women scholars, Aceh Barat

\section{PENDAHULAN}

Masyarakat Aceh secara keseluruhan adalah penganut agama Islam yang dikenal taat beragama. Hal itu terbentuk sejak berabad-abad lalu, sehingga semua itu tercermin dalam berbagai aspek kehidupan, baik dalam perilaku, sistem sosial, sistem ekonomi, kesenian tradisional dan lain-lain sehingga membentuk habitus tersendiri dalam masyarakat Aceh. Budaya Aceh dikenal dengan terjalinnya asimilasi (meusantok) hukum agama dan adat yang tidak dapat dipisahkan. Sehingga dalam masyarakat Aceh dikenal dengan kata pepatah (hadih manja)hukom ngon adatlagee zat ngon sifeut, yang berarti bahwa "hukum Islam dan adat seperti zat dengan sifatnya tak dapat dipisahkan".

Tatanan struktur kehidupan masyarakat Aceh, terdapat relasi pembagian kekuasaan yang masih menempatkan kaum laki-laki berada di atas kaum perempuan. Kaum laki-laki masih diposisikan sebagai pencari nafkah, pemimpin dalam keluarga. Kaum perempuan secara umum masih diposisikan 
pada sektor domestik sebagai istri yang wajib melayani kepentingan suami, dan sebagai ibu yang wajib merawat anak. Hal ini dikarenakan kedudukan laki-laki dan perempuan dalam masyarakat Aceh masih sangat dipengaruhi oleh tafsiran nash-nash agama, budaya dan kepantasan adat. Jika ada laki-laki melibatkan diri dalam sektor rumah tangga, maka masyarakat akan mengatakan donya ka meubalek, bumoe ka diiek ue langet,langet ka ditroun ue bumoe yang berarti "dunia ini sudah terbalik tempatnya, yang seharusnya bumi berada di bawah langit, akan tetapi bumi sudah naik ke langit dan langit sudah turun ke bumi" (Widyanto, 2007: 244).

Kebiasaan masyarakat terbentuk berdasarkan doktrin budaya, adatistiadat dan kebiasaan yang secara turun temurun dianut dan diwariskan. Hal inilah yang mendorong pelegitimasi ketidakadilan gender dalam keluarga masyarakat Aceh. Lebih-lebih lagi kebiasaan tersebut memiliki pengaruh yang kuat dalam alam pikiran mereka seperti ulama dayah tradisional, tokoh-tokoh adat maupun pemerintah. Secara tidak langsung menyetujui apa yang dianut oleh orang tua dalam masyarakat Aceh Barat, terlebih masalah kesetaraan gender anak dalam keluarga (Gani, 2013: 175).

Berdasarkan konteks sosial, sesungguhnya peran perempuan dalam masyarakat Aceh sekarang ini, tidak sebesar peran perempuan dalam kesejarahan Aceh, bahkan perbedaan ini tampaknya sangat kontras. Jika dalam kesejarahan perempuan tampak mempunyai posisi tawar yang kuat, namun dalam konteks sosial sehari-hari perempuan sangat rendah kekuasaannya(powerless). Karena ketika kita bicara antara sejarah dan realita sosial, sesungguhnya kita bicara pada dua konteks yang berbeda.Konteks yang signifikan dalam membicarakan kepemimpinan perempuan di masa lalu adalah kepentingan politik yang ada pada masa itu. Jika ditelisik secara lebih mendalam, maka akan terlihat bahwa peran kepemimpinan perempuan bahkan tidak lepas dari statusnya sebagai identitas biologis perempuan. Artinya, perempuan menjadi pemimpin karena faktor hubungan keluarga dengan tokoh tertentu (laki-laki).

Namun ketika kita bicara realita sosial kontek kekinian, perempuan secara umum di Aceh berada dalam posisi subordinat terhadap laki-laki. Hal ini karena peran dan kedudukan perempuan dalam masyarakat Aceh merupakan konstruksi dan internalisasi sosial yang terbangun atas dasar pemahaman masyarakat atas nilai-nilai kultural dan interpretasi agama Islam sehingga menjadi suatu kebiasaan yang disosialisasikan dalam masyarakat Aceh. Keduanya, nilai-kultural dan interpretasi Islam, sarat dengan muatan patriarkis yang lebih mengutamakan laki-laki daripada perempuan. Pembagian kerja dalam masyarakat Aceh adalah pola pembagian kerja antara laki-laki dan perempuan yang disepakati bersama, serta didasari oleh sikap saling memahami dan saling mengerti karena dikontruksi sedemikian rupa dalam masyarakat Aceh itu sendiri sehingga menjadi kebiasaan (Kurdi, 2014: 29). 
Kenyataan ini terlihat jelas, dimana hal tersebut diciptakan oleh masyarakat terhadap relasi antara laki-laki dan perempuan pada sektor publik dan sektor domestik. Semenjak masa kanak-kanak, pembagian kerja menurut jenis kelamin telah disosialisasikan pada setiap individu. Hal ini dilakukan agar seorang individu mengetahui apa yang menjadi hak dan kewajibannya dalam masyarakat. Atau dengan kata lain, pola sosialisasi yang diterapkan akan membentuk kepribadian seseorang berupa pandangan atas praktik sosial tentang pembagian tugas laki-laki dan perempuan dalam masyarakat (Widyanto, 2007:244).

Kebiasaan dalam masyarakat Aceh, bahwa anak laki-laki yang sudah dewasa tidak tidur di rumah. Biasanya para remaja tersebut tidur di surau (meunasah)bersama-sama dengan kawan-kawannya pada malam hari. Sebaliknya, anak perempuan lebih banyak terlibat dalam tugas-tugas di lingkungan rumah tangga. Penyataan tersebut didukung oleh hasil observasi lapangan, dalam struktur budaya Aceh Barat laki-laki yang berperan besar di ranah publik termasuk dalam belanja keperluan rumah dan perempuan di sektor domestik (mengurus rumah dan anak-anak).

Proses interaksi habitus telah menjadi kebiasaan yang diinternalisasikan antara laki-laki dan perempuan dalam masyarakat Aceh Barat. Yaitu sejak masa kanak-kanak, anak perempuan telah diperkenalkan dengan pekerjaan serta kegiatan lain yang bersifat feminin. Pekerjaan tersebut membutuhkan ketelitian dan ketekunan, seperti menjahit, menganyam, mempersiapkan makanan, ataupunmengasuhanak.Kegiatan-kegiatan yang dapat mengembangkan ketangkasan dan keberanian, seperti berlari, memanjat pohon, ataupun berkelahi tidak diperbolehkan untuk anak mperempuan. Kegiatan-kegiatan seperti ini dianggap hanya pantas dilakukan oleh anak lakilaki (Widyanto, 2007: 246).

Apabila anak perempuan terlihat berada di luar lingkungan rumah, maka orangtua ataupun masyarakat akan menegurnya dengan kalimat lageeagam, cot that aneuknyan, yang berarti "kamu seperti anak laki-laki". Dengan teguran tersebut, kesempatan bagi anak perempuan untuk berada di luar rumah akan terbatasi. Apabila ada kegiatan yang berlangsung di luar rumah seperti belajar mengaji, melihat keramaian, atau upacara upacara tertentu, maka biasanya mereka akan keluar secara bersama-sama dengan wanita lain, tetangga atau teman dan terkadang ditemani saudara-saudaranya. Kesempatan berada di luar lingkungan rumah hanya didapatkan ketika sedang mengikuti kegiatan sekolah.

Berdasarkan gambaran umum yang terjadi di atas, masyarakat Aceh masih secara umum memiliki nilai-nilai patriarkhi yang sangat kental dan melahirkan ketidakadilan gender bagi laki-laki dan perempuan. Stereotipe tersebut disosialisasikan bertahun-tahun diserap dan menjadi baku dalam pola pikir masyarakat. Hal ini mengakibatkan kaum lelaki cenderung dapat 
membela diri dengan mengatakan bahwa sektor domestik adalah kodrat perempuan. Kalimat tersebut sangat sering ditemui, dan bahkan dianggap sebagai kebenaran objektif dari realitas sosial yang ada, khususnya dalam keluarga masyarakat Aceh Barat. Karena pada dasarnya, proses pengambilan peran ini, dimulai dalam keluarga sebelum memasuki sistem sosial yang lebih luas. Secara tidak langsung, dapat dikatakan bahwa keluarga berkecimpung dalam sosialisasi dan pelegitimasian hal tersebut.

Berdasarkan uraian latar belakang masalah bahwa peluang bagi ulama perempuan untuk eksis dan berkontribusi di ranah publik tidak dibatasi oleh sistem pendidikan manapun, baik tradisional maupun modern. Tetapi faktor pengakuan dari masyarakat dan faktor perempuan itu sendiri yang belum siap bergerak ke posisi dan peran yang setara dengan kaum laki-laki, khususnya di ranah elit keagamaan semacam ulama dan juga pengaruh kebiasaan dan sosialbudaya masyarakat. Dengan demkian yang menjadi pokok pembahasan dalam tulisan ini eksistensi dan kontribusi ulama perempuan di Aceh Barat dengan kajian sosiologis.

\section{TINJAUAN PUSTAKA}

\section{a. Ulama dalam Konstek Sosiologis}

Ulama dapat dijelaskan sebagai konsep posisi (jabatan) atau kedudukan dalam konstek sosiologis yang sangat abstrak karena hal ini menyangkut dengan pola, tingkah laku dan hasil interaksi seseorang dalam masyarakat. Demikian pula halnya dengan "posisi ulama perempuan" dalam masyarakat, sangat ditentukan oleh bagaimana pola, tingkah laku, dan interaksi yang dijalin dalam kehidupan mereka sehari-hari dengan masyarakat sehingga diakui sebagai ulama (Purnama: 2006).

Posisi atau jabatan (kedudukan) itu merupakan tanggungjawab, kewajiban serta hak-hak yang sudah ditentukan dalam suatu masyarakat. Sedangkan pola tingkah laku yang diharapkan dari orang-orang pemangku suatu posisi (kedudukan) itu disebut peran. Dengan posisi seseorangdapat menentukan sifat dan tingkatan kewajiban-kewajiban, serta tanggungjawab dalam kelompok masyarakat. Baik posisi maupun peran itu ditentukan oleh tugas, hak dan kewajiban (Narwoko dan Bagong, 2004:156).

Status Ulama merupakan status yang diraih dengan usaha belajar ilmu agama (Achieved status), sehingga perannya dapat berupa kecakapan dalam mengkaji ilmu agama baik dalam pesantren maupun masyarakat luas disebut sebagai "warasatul anbiya" (penerus para nabi).Perannya yang bersifat kultural mencakup Syari'at dan Aqidah. Disamping kewibawaan dan ketauladanan yang menjadi parameter keberhasilannya dalam menuntun umatnya ke arah kemuliaan agama. Menurut Linton seseorang yang menjalankan peran 
manakala ia menjalankan hak dan kewajiban yang sesuai dengan statusnya.

Kepemipinan (leadership) itu sendiri merupakan kemampuan seseorang untuk mempengaruhi orang yang dipimpinnya, sehingga orang lain tersebut bertingkah laku sebagaimana dikehendaki oleh pemimpin tersebut. Dilihat dari kedudukannya, kepemimpinan merupakan suatu komplek dari hak-hak dan kewajiban yang dapat dimiliki oleh seseorang atau suatu badan dan juga peran yang melekat pada orang atau sistem tersebut. Ketika kita merujuk pada prinsip kepemimpinan, ulama pesantren atau dayah cenderung bersifat kepemimpinan informal. Oleh karena itu yang diteliti dalam penelitian ini adalah pandangan tokoh-tokoh pesantren atas posisi dan eksistensi ulama prempuan, maka tipe kepemimpinan (informal) yang menjadi sasaran penelitian.

\section{b. Definisi Konsep}

1. Eksistensi berasal dari bahasa latinexistere yang artinya muncul, ada, timbul, memiliki keberadaan aktual. Existere disusun dari ex yang artinya keluar dan sistere yang artinya tampil atau muncul.Dalam kamus bahasa Indonesia, eksistensi diartikan sebagai keberadaan (wikipedia). Eksistensi yang dimaksud dalam penelitian ini mengacu pada pembuktian diri atas keberadaannya (posisi ulama) diakui orang lain, masyarakat (tokoh-tokoh pesantren). Artinya, eksistensi menjelaskan tentang penilaian ada atau tidak adanya pengaruh terhadap keberadaan seseorang tersebut.

2. Ulama: berasal dari bahasa Arab yaitu العلىـاء Ulamā', tunggal عالِ 'Ālim) adalah pemuka agama atau pemimpin agama yang bertugas untuk mengayomi, membina dan membimbing umat Islam baik dalam masalahagama maupum masalah sehari hari yang diperlukan baik dari sisi keagamaan maupun sosial kemasyarakatan. Dalam masyarakat Aceh Barat seseorang ulama baru benar-benar diakui sebagai ulama, jika telah diakui oleh masyarakat itu sendiri sebagai ulama.

3. Ulama Perempuan adalah cendikiawan, intelektual pemuka agama Islam, tokoh perempuan yang dilandasi kompetensi religius (Purnama: 2006). Dalam masyarakat Aceh, ulama perempuan sering juga di sebut sebagai teungku atau ummi, istri ulama juga sering juga disebut dengan ummi atau bunda (guru-guru pengajianperempuan). Teungku, ummi maupun bunda adalah panggilan terhadap guru pengajian dalam masyarakat Aceh. Teungku atau ummi baru diakui sebagai Ulama dalam masyarak Aceh khususnya Aceh Barat yang telah memiliki pengetahuan tentang Agama serta mendapat pengakuan dari masyarakat sebagai ulama perempuan (Dahlan: 1999). 


\section{METODE PENELITIAN}

Metode penelitian yang digunakan dalam kajian ini adalah penelitian kualitatif. Tipe penelitian ini adalah studi kasus karena peneliti ingin mendapatkan pemahaman yang lebih baik tentang eksistensi ulama perempuansebagai suatu analisis sosiologis.Penelitian kualitatif ini bersifat deskriptif, dimana peneliti berupaya untuk sampai pada explanatory understanding, yang mengandalkan pengamatan, studi dokumentasi, dan wawancara mendalam dengan subjek yang dipilih menjadi key informan. Dengan teknik tersebut peneliti berada pada posisi untuk melihat seberapa jauh informan "mengatakan apa yang mereka maksudkan" dan "maksud apa yang mereka katakan". Peneliti dalam hal ini berusaha untuk menangkap proses interpretasi produk praktik sosial, cara aktor menafsirkan peristiwa dalam bentuk eksistensi sosial yang didasarkan pada kebiaasaan dalam masyarakat. Analisis data yang digunakan dalam penelitian ini terdiri atas tiga alur kegiatan yaitu: (1) reduksi data, (2) penyajian data, dan (3) penarikan kesimpulan (Bungin, 2003: 244). Pada tahap pertama, dilakukan reduksi data yaitu peneliti membaca, mengkaji dan menelusuri data yang berhasil dikumpulkan dari hasil wawancara, observasi, dan studi dokumentasi

\section{TEMUAN DAN PEMBAHASAN}

Agama Islam, mewajibkan perempuan menuntut ilmu pengetahuan sama seperti halnya laki-laki. Islam menyamakan perempuan dan laki-laki dalam kewajiban-kewajiban keagamaan serta dalam hal menuntut ilmu. Hal ini dipertegaskan dalam hadis (perkataan Rasulullah SAW): "Menuntut ilmu adalah kewajiban bagi setiap muslim perempuan dan laki-laki" tanpa perbedaan. Tidak ada pengecualian bagi laki-laki maupun perempuan dalam menuntut ilmu. Namundalam pelaksanaannya terlihat ada perbedaan antara laki-laki dan perempuandalam masyarakat. Hal ini didasarkan padastereotip dalam masyarakat umum yang diberikan pada laki-laki dan perempuan.

Kebiasaan tersebut memberi pemahaman yang berbeda yang cenderung menjadi kebiasaan terhadap perempuan sebagai pasangan pemimpin dan pengikutnya. perwujudan kesetaraan gender dalam berkontribusi di ranah publik dilakukan karena berbagai hal yang berkaitan dengan perempuan menduduki posisi lemah (Purnama:2006). Eksistensi dan kontribusi ulama perempuan yang hampir tidak ditemukan itu adalah karena kebiasaan yang berkembang dalam masyarakat dari kalangan laki-laki yang eksis dan berkontribusi di ranah publik dan diakui dalam masyarakat bersangkutan.

Pengakuan masyarakat Aceh terhadap eksistensi dan kontribusi ulama 
perempuan sering sekali tergantung pada kebiasaan dan sosial-budaya setempat serta jenis pendidikan (salafi maupun terpadu) yang diperoleh mereka dalam dayah maupun pergaulannya dalam masyarakat. Menurut sebagian informan masyarakat Aceh Barat memandang perempuan dari sudut perbedaan biologis. Kedudukan perempuan secara biologis lemah direfleksikan oleh masyarakat pada semua sektor lain yang tidak secara langsung berkaitan dengan kelemahan fisikal. Padahal secara interlektual dan darisegi rasionalitas perempuan mampu mensejajarkan eksistensinya dengan laki-laki, utamanya pada capaian-capaian ilmu pengetahuan.

Setiap struktur masyarakat mendefinisikan peran laki dan perempuan secara berbeda. Namun alokasi peran kaum laki-laki sebagai peran publik dan perempuan domestik terdapat dihampir pada semua masyarakat. Pembagian peran berdasarkan jenis kelamin ini telah di sosialisasikan sejak masih kecil. Proses sosialisasi dan internalisasi nilai tersebut pertama berlangsung dalam keluarga sebagai unit masyarakat yang paling fundanmental. Selanjutnya lembaga pendidikan (dayah) turut menyempurnakan proses sosialisasi tersebut. Sesuai dengan kondisi sosial budaya masyarakat(Sudarwati, 1997: 2).

Kodrat wanita adalah sebagai istri dan ibu, dalam sudut pandang masyarakat tradisional terutama dalam masyarakat patriarkat tempat perempuan adalah di rumah. Status perempuan dalam keluarga diawali dari kedudukannya sebagai anak, istri dan ibu.Kehidupan masyarakat Aceh Barat hampir sama dengan kehidupan msayarakat jawa yang di jelaskandalam studi Sudarwati (1997), dimana struktur masyarakat yang menonjolkan peran dominan kaum pria, dalam struktur sosial. Berarti selama berlangsungnya sosialisasi anggota masyarakat diperlakukan sesuai jenis kelamin, kaum lakilaki cenderung peran publik dan kaum perempuan peran domestik.

Dengan posisi semacam ini, seorang perempuan alumni dayah menjadi sangat sulit mengorbitkan dirinya atau eksis menjadi ulama seperti kaum lakilaki yang relatif tidak mengalami hambatan-hambatan serupa. Kebanyakan santri perempuan di lembaga dayah, dimana kesempatan belajar agama dan menyiapkan diri untuk menjadi seorang ilmuan muslim (ulama) tidak semudah yang dijalani santri laki-laki. Dengan demikian bagaimana mungkin ia memiliki waktu dan kesempatan maksimal untuk menguasai ilmu pengetahui sebagai prasyarat dalam mengantar dirinya ke gerbang keulamaan (Sudarwati:1997).

\section{a. Ulama Perempuan Suatu Kenyataan}

Ulama dalam masyarakat Aceh dipandang sebagai figur yang serba bisa baik dibidang ibadah, mu'amalah (sosial) maupun bidang siyasah (hukum). Bahkan untuk menentukan aturan yang sangat penting, seperti boleh tidaknya seorang perempuan menjadi pemimpin, dibutuhkan otoritas dan peran orangorang yang termasuk kategori ulama (Imran: 2000). 
Kecamatan (Kaway XVI dan Woyla) memperlihatkan pemahaman positif masyarakat yang didukung realitas ulama perempuan. Ditemukan figur ulama perempuan yang legitim dalam masyarakat bersangkutan dengan kualifikasi (kapasitas dan kompetensi) yang kondusif bagi kepemimpinan dalam bidang keagamaan, sosial-budaya, politik dan mengasuh dayah dalam masyarakat. Ulama perempuan yang independen dalam ranah publik, memiliki kemampuan menyerukan pandangan-pandangannya kepada publik. Namun persyaratan itu tidak lengkap sebagaimana dimiliki laki-laki, yakni tidak sesuai dengan doktrin agama yang memandang suara perempuan sebagai aurat dan sosial-budaya. Dalam konteks ini pengetahuan masyarakat mengenai ulama perempuan kurang-lebih didasarkan pada pengalaman empirik kasus Umi Hanisah, Umi Nur Aini Manan (ketua dan wakil ulama perempuan di Kabupaten Aceh Barat).

Forum ulama perempuan di Kabupaten Aceh Barat mulai eksis sejak tahun 2005, yang dipelopori dan disosialisasikan oleh umi Hanisah. Sebagai ulama perempuan Umi Hanisah dan Umi Nuraini Manan telah mampu memberikan pengaruh sosial politik dan dorongan serta wawasan pada masyarakat bersangkutan.

Berdasarkan kasus ulama tersebut dapat diketahui bahwa memiliki kemampuan yang berpengaruh dalam bidang sosial politik merupakan salah satu persyaratan yang berlaku dalam kaitan seseorang diakui sebagai ulama. Hal tersebut mengakibatkan keberadaan ulama perempuan sangat sulit tampil dan diakui dalam masyarakat, bukan berarti tidak ada, karena ulama perempuan suatu kenyatan dari zaman dulu hingga sekarang.

Menurut Purnama (2006:81), ulama perempuan yang jarang ditemukan diranah publik dalam masyarakat Aceh, itu karena tidak memenuhi kriteria ulama sebagaimana berkembang di kalangan laki-laki, yakni mampu menjadi pemimpin publik yang diakui dalam masyarakat bersangkutan. Berbagai doktrin atau dogma yang dihayati dan diamalkan masyarakat sejak masa silam dijadikan tameng untuk melestarikan pembagian kerja antara laki-laki dan perempuan yang bias gender dan didukung oleh pandangan sosio-biologis.

Meskipun agama Islam telah memberikan berbagai hak, kehormatan, dan kewajiban kepada perempuan sesuai dengan harkat dan martabat mereka sebagai makhluk yang bertanggung jawab dihadapan Allah baik terhadap diri, keluarga, masyarakat maupun negara. Jika Allah saja telah memberikan hak dan tanggung jawab kepada kaum perempuan, apa lagi "manusia" sebagai hamba-Nya. Karena itu tidak ada alasan bagi kaum laki-laki untuk merasa superior terhadap jender perempuan. Selain itu, menolak perempuan untuk tampil di ranah publik maupun dipentas politik berarti mendiskreditkan kaum perempuan termasuk dalam bidang agama sebagai ulama perempuan yang sejajar dengan laki-laki. 


\section{b. Pemahaman Masyarakat tentang Eksistensi Ulama Perempuan}

Secara umum eksistensi dan kontribusi ulama perempuan dalam masyarakat Aceh Barat masih dipahami dalam kapasitas perempuan. Ulama perempuan sudah berkembang di kalangan publik, namun hal itu masih kurang mendapat respon yang positif, utamanya dari kaum laki-laki. Kontribusi ulama perempuan belum memiliki dampak yang luas karena ulama perempuan tidak mendapat kesempatan yang sama dengan ulama laki-laki untuk membuktikan kemampuannya di ruang publik. Peluang yang dapat dimanfaatkan ulama perempuan adalah mencerdaskan kaum perempuan dalam bidangnya atau masih dalam kapasitas perempuan dan ruang geraknya terbatas.

Menurut informan di Kecamatan Kaway XVI ada sejumlah ulama perempuanyang berkontribusi diruang atau ranah publik. Kontribusi mereka dalam memperingati hari besar agama Islam dengan mengisi ceramah, mengisi pengajian dan memperdayakan masyarakat. Sehingga dalam beberapa hal dapat disebutkan sebagai "eksistensi dan kontribusi ulama perempuan". Karena secara formal mereka mampu mengurus kepentingan masyarakat umum, utamanya masalah pembedayaan perempuan, keagamaan dan kesejahteraan bersama. Ulama perempuan yang dikemukakan informan tersebut memenuhi kriteria pendidikan yang layak, mengasuh atau memimpin dayah, memiliki kharismatik dan integritas moral, mempunyai kemampuan dalam bidang agama, serta aktif dalam upaya penyebaran syiar Islam (wawancara dengan Abon Basri Juned Pengasuh Dayah Darussalamh, Kecamatan Kaway XVI tanggal 16 Maret 2015).

Eksistensi dan kontribusi ulama perempuan dalam masyarakat, dipahami masyarakat Aceh masih dalam kapasitas perempuan. Perempuan belum dimungkinkan berkontribusi dalam ranah publik, hanya dalam majelis taklim, ceramah khusus untuk atau sesama perempuan dan juru dakwah lokal. Kehadiran ulama perempuan di ruang publik (MPU) sebagai keterwakilan dari perempuan. Jadi kalaupun ulama perempuan berkotribusi secara sosial-politik hanya ikut serta pada lembaga sosial politik untuk memperoleh keterwakilan perempuan. Kebiasaan ini dikontruksi dan diinternalisasi secara terus-menerus melalui seretetan tahapan (habitus, modal dan ranah) dalam masyarakat kepada individu sehingga ditampilkan dalam praktik sosial terhadap pokok permasalahan yang menjadi perhatian.

Hasil wawancara dengan para informan di Kabupaten Aceh Barat dan observasi dilapangan memberikan informasi bahwa pemahaman masyarakat Aceh Barat terhadap ulama perempuan banyak ditentukan oleh kondisi sosialbudaya mereka yang telah dihayati dan diamalkan secara turun-temurun. Berbagai doktrin atau dogma serta kebiasaan yang dihayati dan diamalkan masyarakat sejak masa silam dijadikan tameng untuk melestarikan cara pandang terhadap pembagian kerja antara laki-laki dan perempuan yang bias 
gender dan didukung oleh pandangan sosio-biologis, sosio-psikologis dan dan sosio-religius.Kondisi sosial budaya yang sudah terstruktur menjadi sistem nilai, sebagai mekanisme kontrol ke dalam masyarakat bersangkutan. Sistem nilai tersebut sudah mentradisi dan tidak mudah lagi untuk diredefinisi dalam masyarakat bersangkutan (Purnama:2006). Sehingga eksistensi dan kontribusi ulama perempuan yang sudah diterima dalam masyarakat Aceh Barat masih dalam kapasitas perempuan.

\section{c. Peluang Eksistensi Ulama Perempuan dalam Masyarakat}

Peluang yang dapat dimanfaatkan oleh ulama perempuan dalam pembangunan sosial-budaya maupun agama dapat dilakukan, terutamanya untuk kaum mereka sendiri atau dalam kapasitas perempuan. Menurut beberapa informan eksistensi ulama perempuansudah pasif atas perkembangan sosial-keagamaan dan politik terkini. Pendidikan kritis dapat disediakan kepada kaum perempuan agar mereka dapat memberikan respon pada pengambilan keputusan-keputusanpolitik yang tidak memberdayakan merekadan kemungkinan generasinya (Purnama:2006).

Peluang yang dapat dimanfaat oleh ulama perempuan dengan adanya Keputusan Majelis Permusyawaratan Ulama Aceh, nomor 15 tahun 2012 tentang hasil muzakarah ulama perempuan MPU Aceh tahun 2012 revitalisasi kedudukan dan peran ulama perempuan dalam pembinaan generasi bangsa. Pertama kedudukan ulama perempuan sebagai mitra ulama laki-laki, kedua adanya peran ulama perempuan sebagai mediator dalam persoalan keluarga, oleh karena itu perlu pengkaderan, ketiga adanya alokasi dana dari pemerintah untuk terialisasinya peran ulama perempuan dalam pelaksanaan syariat Islam di Aceh. Keempat ulama perempuan harus dilibatkan dalam menyikapi berbagai persoalan ummat dan, kelima perlu adanya pertemuan ulama perempuan serumpun (Asia Tenggara).

Seorang ummi atau teungku inoeng, sebenarnya adalah alumni dayah, sama dengan ulama laki-laki. Peluang yang sama pun diakui dalan qanun meskipun ulama perempuan ada pembagian peran secara khusus dengan sesama perempuan. Hal ini menandakan bahwa iklim akademis di dayah maupun pemerintah Aceh (keputusan qanun) memberikan kesempatan dan peluang yang sama dengan calon ulama laki-laki (santri laki-laki) untuk meretas jalan menjadi seorang kader ulama. Namun, kendala terbesar yang dihadapi santri perempuan untuk eksis menjadi seorang ulama adalah dirinya sendiri (sosio-biologis) dan kebiasaan dalam masyarakat, bukan sistem pendidikan di dayah. Sistem pemerintahan demokratis yang telah diterima sebagian besar masyarakat Aceh diharapkan dapat memberikan peluang bagi tumbuhnya konstruksi sosial-budaya yang lebih seimbang (gender equality) antara laki-laki dan perempuan dalam bermasyarakat dan bernegara. 
Menurut Purnama (2006:23), perubahan konsep pemahaman dan pemikiran masyarakat terhadap ulama perempuan maupun dari status ulama kharismatik ke traditional-rasional melalui perubahan habit dan pencerahan melalui pendidikan. Kontribusi lain yang mungkin dikembangkan oleh ulama perempuan dalam proses pelaksanaan pembangunan masyarakat di Kabupaten Aceh Barat adalah bagaimana masyarakat dapat memahami perubahan sosialbudaya dan kebiasaan. Dengan kemajuan ilmu pengetahuan dan sifat keterbukaan dalam masyarakat memungkinkan memperoleh pengetahuan tentang pergeseran peran dan kontribusi ulama dalam masyarakat. Ulama perempuan harus mampu menempati diri dalam kapasitas ibu bagi anak-anak dan isteri yang baik buat suami, baik dari sudut pandang agama maupun adatistiadat dan budaya dalam masyarakat. Dengan demikian diharapkan kehadiran ulama perempuan ke depan akan semakin lebih diterima oleh masyarakat Aceh secara luas dan masyarakat Aceh Barat secara khusus.

Masyarakat menerima eksistensi dan kontribusi ulama perempuan sejauh mampu menempati diri dalam kapasitas ibu bagi anak-anak dan isteri yang baik buat suami, baik dalam kacamata agama maupun kacamata adatistiadat dan budaya dalam masyarakat. Menurut beberapa informan, jika seorang ulama perempuan mampu menempati diri dalam masyarakat, eksistensi dan kontribusi atau kehadiran ulama perempuan ke depan akan semakin lebih diterima oleh masyarakat Aceh secara luas dan masyarakat Aceh Barat secara khusus. Dengan demikian eksistensi ulama perempuan sangat tergantung pada bagaimana ulama perempuan menempati diri dalam masyarakat.

Bagaimana pun juga perubahan sosial menyentuh konsep-konsep ulama dari status ulama laki-laki ke ulama perempuan dan ulama karismatik menuju tradisional dan rasional merupakan peluang bagi ulama perempuan untuk mendapat pengakuan dari masyarakat. Sejauhini eksistensi dan kontribusi ulama perempuan diterima tokoh-tokoh dayah sebagai representasi masyarakat Aceh Barat masih dalam kapasitas perempuan. Untuk merubah pola pikir ulama dayah terhadap keikutsertaan perempuan dalam berbagai lini kehidupan khususya dalam ranah publik tidak muncul dengan sendirinya. Akan tertapi melalui proses panjang dengan perjuangan yang gigih yang dilakukan oleh sejumlah pemikir.

\section{d. Hambatau Eksistensi dan Kontribusi Ulama Perempuan}

Kondisi masyarakat Aceh Barat sekarang masih banyak mengharapkan pengkonstruksian (kemunculan atau perulangan kebiasaan) ulama yang menjadi panutan adalah laki-laki. Dalam pemahaman yang berkembang di kalangan masyarakat Aceh Barat, ulama diartikan sebagai figur yang memenuhi kriteria bahwa ulama bersangkutan ahli dalam ilmu agama Islam, 
mempunyai intergritas pribadi yang tinggi dan mulia, berakhlak mulia, dan memiliki kharisma. Ulama juga orang-orang yang dipandang sangat berpengaruh ditengah-tengah masyarakat,yakni orang-orang yang kuat dan luas pengetahuan agamanya. Mereka sanggup melaksanakan ilmu pengetahuannya melalui ibadah dan amal perbuatan yang nyata yaitu berkontribusi dalam masyarakat, serta ketakwanya kepada Allah dan diakui oleh masyarakat (Purnama:2006).

Berdasarkan beberapa hal tersebut, maka dapat dikatakan bahwa ajaran Islam menjadi hukum dalam masyarakat Aceh telah berlangsung relatif lama, dengan berindikasi pada kehidupan masyarakat Aceh yang tidak dapat dipisahkan dari sistem adat dan nilai budaya keislaman. Nilai-nilai keislaman begitu kental dan menyatu dengan adat. Bahkan dalam hal tertentu "adat" dipandang indentik dengan "agama". Kedua bila ada di antara anggota keluarga melakukan pelanggaran norma, baik norma agama maupun adat, akan berakibat aib dan malu bukan pada diri saja tertapi keluarga ikut menanggungnya. (Gani , 2013:188).

Eksistensi dan kontribusi ulama perempuan dalam masyarakat menurut sebagian informan menganggapmasih tabu. Dalam realitasnya, laki-lakisering tampil di ranah publik, sehingga meniimbulkan kecurigaan tentang eksistensi maupun kontribusi ulama perempuan, masalah bisa atau tidak dalam agama ataupun kepantasan adat, karena belum pernah ada dari dulu ulama perempuan di Aceh Barat tampil dalam ranah publik. Oleh karena itu eksistensi dan kontribusi ulama perempuan yang diterima masyarakat Aceh Barat masih dalam kapasitas perempuan. Kontribusi ulama perempuan dipahamisebagai juru dakwah lokal, majelis taklim sebagai media pembelajaran masyarakat, ceramah khusus untuk perempuan dan dalam bidang acara sosial keagamaan (Purnama:2006).

Berdasarkan dari hasil wawancara mendalam peneliti dengan informan menurutnya perempuan banyak hambatannya dalam berinteraksi di ranah publik. Seorang perempuan yang naik haji harus ada muhrim apa lagi dalam berdakwa, karena perempuan diibaratkan seperti bunga yang harus dijaga dari berbagai hal yang menimbulkan fitnah. Dengan demikian dapat disimpulkan bahwa para informan memahami dan menerima eksistensiulama perempuan masih dalam kapasitas perempuan sesuai dengan pemahaman yang dihayati bersama oleh mereka dalam praktik sosial. Walaupun kemampuan perempuan melebihi laki-laki tapi kepantasan adat dan agama yang telah dipahami masyarakat harus diperhatikan. Ulama laki-laki yang biasa berperan dan berkontribusi dalam masyarakat, sehingga pemahaman atau pandangan masyarakat terbangun dari kebiasaan yang ada. Dengan demikian dapat disimpulkan bahwa kebiasaan dan pemahaman terhadap nilai-nilai (agama, adat-istiadat) yang ada dalam masyarakat sebagai nilai pembenaran terhadap eksistensi dan kontribusi ulama perempuan di publik. 
Meskipun ada kecenderungan bahwa yang mengikuti pendidikan didayah, misalnya memperoleh capaian prestasi sama, bahkan lebih tinggi dibandingkan dengan laki-laki dalam bidang agama. Kondisi ini memperlihatkan ada potensi dan peluang yang dimiliki perempuan untuk eksis dan berkontribusi sama dalam ranah publik. Namun, kondisi sosial budaya dan kebiasaan masyarakat yang ditampilkan atau berkontribusi lakilaki dalam pergaulan dan komunitas atau masyarakat masih bias laki-laki, dimana laki-laki lebih arogan secara biologis menunjukkan keakuan (diakui) dan keandalan secara fisik dan didukung dogma-dogma (agama maupun sosial-budaya) serta nilai tradisional dan kebiasaan yang meruntuhkan mental perempuan.

Komunitas atau masyarakat Aceh Barat tidak mendapat peluang untuk berubah secara institusional karena berbagai hal yang tidak dapat dijelaskan secara konkrit-rasional. Kaum perempuan dipandang sebagian informan tidak mempunyai cita-cita untuk menjadi tokoh, apalagi ulama perempuan, sebagai public figure yang memiliki kapasitas dan kompetensi dalam bidang-bidang kehidupan sosial-politik untuk memajukan masyarakat. Kebiasaan dan nilai agama dan budaya yang tumbuh dan berkembang serta dihayati bersama melalui proses pendidikan (dayah) yang dikontruksikan dan diinternalisasikan secara terus-menerus pada anggota masyarakat dan ditampilkan kembali dalam bentuk praktik sosial bahwa perempuan dipandang hanya pantas berkontribusi dalam kapasitas perempuan (mendapat pengakuan).

Dengan demikian dapat dikatakan, faktor utama yang menghambat eksistensi ulama perempuan adalah atmosfer kebudayaan atau tradisi dan kebiasaan dalam masyarakat Aceh yang tidak mendukung. Perempuan cenderung mengambil tempat atau ditempatkan pada posisi sub-ordinat atau marginal (Burhanuddin, 2002). Menurut pimpinan dayah Serambi Mekkah, tidak mudah dan boleh dikatakan sangat jarang seorang santri perempuan mampu bertahan dalam studinya di dayah, sampai dengan lulus dan akhirnya mendapat legalitas keulamaan. Bahkan relatif terbatas bagi seorang santri perempuan mampu mencapai kelas atas dalam dayah (semisal kelas VII, VIII dan IX). Kebanyakan mereka harus kembali kepada keluarga di tengah jalan (kelas pertengahan) atau menjelang akhir studi (kelas tinggi).

Hal tersebut lebih disebabkan faktor psikologis menyangkut usia subur atau produktif seorang perempuan saatnya berkeluarga, faktor sosiologis dimana masyarakat akan mencibir bila ada seorang perempuan yang berlamalama membujang (belum nikah), maupun faktor biologis dimana ia harus menjadi seorang istri dan melahirkan anak-anak mereka. Proses seseorang menjadi ulama melalui pendidikan dayah menjadi indikator penting untuk memperoleh pengakuan (tokoh-tokoh dayah maupun masyarakat tempatan) sebagai ulama (Sudarwati:1997). 
Hambatan biologis, psikologis serta peran domistik dan kultural itulah yang selama ini menghalangi kaum perempuan meraih posisi klimak di domain publik terutama di dunia pendidikan baik agama maupun umum. Ulama adalah gelar akademis lembaga pendidikan dayah, tetapi sekaligus gelar sosiologis yang tidak semua alumni dayah mampu memperolehnya. Ulama perempuan adalah istilah baru yang masih dirasa asing dan dianggap tabu serta dicurigai ketika digunakan dalam ungkapan sehari-hari. Sistem pendidikan dayah, karenanya tidak menjamin mengantarkan seorang santri untuk meraih titel ulama. Dayah dalam kapasitasnya sebagai institusi pendidikan keagamaan bertugas mendidik dan menyiapkan kader (calon) ulama, bukan mencetak ulama. Masyarakatlah akhirnya yang berhak memberi label seorang alumni dayah apakah ia berhak diberi gelar ulama atau sebatas gelar keagamaan biasa, sebatas teungku atau ustaz/ustazah (guru agama).

\section{KESIMPULAN}

Ulama dalam masyarakat Aceh dipandang sebagai figur yang serba bisa baik dibidang ibadah, mu'amalah (sosial) maupun bidang siyasah (hukum). Bahkan untuk menentukan aturan yang sangat penting, seperti boleh tidaknya seorang perempuan menjadi pemimpin, dibutuhkan otoritas dan peran orangorang yang termasuk kategori ulama (Imran: 2000).

Tatanan struktur kehidupan masyarakat Aceh, terdapat relasi pembagian kekuasaan yang masih menempatkan kaum laki-laki berada di atas kaum perempuan. Kaum laki-laki masih diposisikan sebagai pencari nafkah, pemimpin dalam keluarga. Kaum perempuan secara umum masih diposisikan pada sektor domestik sebagai istri yang wajib melayani kepentingan suami, dan sebagai ibu yang wajib merawat anak. Hal ini dikarenakan kedudukan laki-laki dan perempuan dalam masyarakat Aceh masih sangat dipengaruhi oleh tafsiran nash-nash agama, budaya dan kepantasan adat.

Masyarakat Aceh Barat menerima eksistensi dan kontribusi ulama perempuan sejauh mampu menempati diri dalam kapasitas ibu bagi anak-anak dan isteri yang baik buat suami, baik dalam kacamata agama maupun kacamata adat-istiadat dan budaya dalam masyarakat. Menurut beberapa informan, jika seorang ulama perempuan mampu menempati diri dalam masyarakat, eksistensi dan kontribusi atau kehadiran ulama perempuan ke depan akan semakin lebih diterima oleh masyarakat Aceh secara luas dan masyarakat Aceh Barat secara khusus. Dengan demikian eksistensi ulama perempuan sangat tergantung pada bagaimana ulama perempuan menempati diri dalam masyarakat.

\section{DAFTAR PUSTAKA}

\section{Buku}

Abdullah, Taufik (ed).1996. Agamadan Perubahan Sosial. Jakarta : Raja Grasindo 
Persada.

Adlin, Alfathri. 2009. Resistensi Gaya Hidup: Teori dan Realitas. Jakarta: Jalasutra

Arikunto, Suharsimi. 2006. Prosedur Penelitian: Suatu Pendekatan Praktik.Jakarta: Rineka Cipta.

Badan Pusat Statistik. 2014. Aceh Barat Dalam Angka, Banda Aceh: Badan Pusat Statistik

Berger, L, Peter dan Thomas Luckmann. 1990. Tafsir Sosial atas Kenyataan(terjemahan Hasan Basri) Jakarta: LP3ES.

Bourdieu, Piere. 1990. The Logic of Practice. USA: Standaford University Press

Burhanuddin, Jajat. 2002. Ulama Perempuan Indonesia. Jakarta: Gramedia Pustaka Utama.

Bungin, Burhan. 2007. Penelitian Kuantitatif dan Kualitatif. Jakarta: Kencana Media Group

Jenkins, Richard. 2004. Membaca Pikiran Pierre Bourdieu. Jakarta: Kreasi Wacana.

Kurdi, Muliadi. 2014. Menelusuri Karakteristik Masyarakat Desa: Pendekatan Sosiologi Budaya Dalam Masyarakat Aceh. Banda Aceh: Yayasan PeNA.

Suni, Ismail. 1980. Bunga Rampai tentang Aceh. Jakarta: Bharata Karya Aksara.

Umar, Nasaruddin. 1999. Argumen Kesetaraan Jender: Perspektif Al-Qur'an. Jakarta: Paramadina. Cet. I.

Widyanto, Anton. dkk. 2007. Menyorot Nanggroe: Refleksi Kegundahan atas Fenomena Keagamaan, Pendidikan, Politik, Kepemerintahan, Gerder dan SosialBudaya Aceh. Banda Aceh: Yayasan PeNa.

\section{$\underline{\text { Tesis, Jurnal dan Penelitian Ilmiah }}$}

Adib, Mohammad. Agen dan Struktur dalam Pandangan Pierre Bourdieu, Jurnal Bio Kultur, Vol I, No. 2, Juli-Desember, 2012.

Abduh Wahid. Perempuan Aceh antara Budaya dan Syariat. Jurnal Subtantia. Vol. 12. No. 02. Oktober 2010.

Kasjim, Salenda. Kepemimpinan Perempuan dalam Perspektif Islam. Jurnal Ilmiah: Ar-Risalah Makasar. Vol. 12. No.2 Nopember 2012.

Marzuki. 2012. Kepemimpinan Perempuan dalam Perspektif Ulama Pesantren di Aceh. Jurnal Ilmiah: Akademika. Vol. 19. No. 01. Januari-Juni 2014.

Purnama, Eddy dan Jalil, Husni at.al. 2006.Persepsi Masyarakat Aceh Terhadap Ulama Perempuan di Provinsi Nanggroe Aceh Darussalam. 
Penelitian Ilmiah. Banda Aceh: Unsyiah.

Raihan, Putri. 1997. Kedudukan Perempuan Di Aceh. Banda Aceh: Penelitian Pusat Studi Wanita Institut Agama Islam Negeri (IAIN) Ar-Raniry.

Sudarwati, Lina. 1997. Keluarga dan Pendidikan Perempuan di Pesantren (Kasus

di Kabupaten Sleman dan Bantul Yogyakarta). Tesis. Pasca Sarjana

Universtas Gajah Mada (UGM) : Yogyakarta.

\section{Situs Internet/ Website}

Departemen Agama RI, Ensikoledi Islam, (Jakarta: Departemen Agama RI, 1993),

https://www.google.com/search.Cut+Nyak+Meutia+_dakwah.info.htmdiakse s Januari 2015

http://www.rahima.or.id/:fokus-edisi-34-menegaskan-eksistensi-ulama perempuan-untuk-kemaslahat manusia diakses Febuari 2015. 